\title{
Sistem Pendukung Keputusan dalam Pemilihan Juara Umum pada SMP Negeri 3 Kota Bengkulu
}

\author{
Indra Kanedi ${ }^{1}$ \\ ${ }^{1}$ Dosen Tetap Program Studi Sistem Informasi Fakultas Ilmu Komputer Universitas Dehasen Bengkulu \\ Jl. Meranti Raya No. 32 Kota Bengkulu 38228 Telp. (0736) 22027, 26957 Fax. (0736) 341139; e-mail: indra@unived.ac.id)
}

\begin{abstract}
As a formal educational institution level junior, Junior High School 03 City try to apply all existing activities with computer-based scheduling both in terms of subjects, preparing reports or other activities that require the existence of a computer as a tool. To be able to bridge the problems faced by SMP -3 Bengkulu City in determining the overall winner of each successive grade class rank is to build a program that is built using a programming language. While the methods used in the decision-making concept is the method of Simple Additive Weighting (SAW). Decision support system (DSS) is a computer-based information system that produces a variety of alternative decisions to assist management in dealing with various problems in a structured or unstructured using data and models. The benefits of a decision support system is the right decision, according to the types of decisions necessary, make forecasts, comparing alternative actions, making the analysis of the impact, and create a model. SAW method can solve complex problems, where the criteria taken quite a lot, structural problems that remain unclear, the uncertainty perceptions of decision makers as well as the uncertainty of the availability of accurate statistics. From the results of the study using the program decision support system for selecting the students overall champion class rise in SMP Negeri 3 Bengkulu City showed that the program greatly help the school in choosing the overall winner grade. Where the process is carried out very quickly and practically and objectively because the calculation is performed in the program.
\end{abstract}

Keyword: Visual Basic, Decision Support System, SAW

Intisari- Sebagai sebuah lembaga pendidikan formal tingkat lanjutan pertama, SMP Negeri 03 Kota mencoba menerapkan semua aktifitas yang ada dengan berbasis komputer baik dalam hal penyusunan jadwal mata pelajaran, pembuatan laporan maupun aktifitas lain yang memerlukan keberadaan komputer sebagai alat bantu. Untuk dapat menjembatani permasalahan yang dihadapi SMP Negeri -3 Kota Bengkulu dalam menentukan juara umum peringkat kelas setiap kenaikan kelas tersebut adalah dengan membangun sebuah program yang dibangun dengan menggunakan bahasa pemrograman. Sedangkan metode yang digunakan pada konsep pengambilan keputusan tersebut adalah dengan metode Simple Additive Weighting (SAW), Sistem pendukung keputusan (SPK) adalah suatu sistem informasi berbasis komputer yang menghasilkan berbagai alternatif keputusan untuk membantu manajemen dalam menangani berbagai permasalahan yang terstruktur ataupun tidak terstruktur dengan menggunakan data dan model. Manfaat dari sistem pendukung keputusan adalah pengambilan keputusan yang tepat, sesuai dengan jenis keputusan yang diperlukan, membuat peramalan, membandingkan alternatif tindakan, membuat analisis dampak, serta membuat model. Metode SAW dapat memecahkan masalah kompleks, dimana kriteria yang diambil cukup banyak, struktur masalah yang belum jelas, ketidakpastian persepsi pembuat keputusan serta ketidakpastian tersedianya data statistik yang akurat.Dari hasil penelitian dengan menggunakan program Sistem Pendukung Keputusan Dalam Pemilihan Juara Umum Pada Smp Negeri 3 Kota Bengkulu didapatkan hasil bahwa dengan program tersebut sangat membantu pihak sekolah dalam melakukan pemilihan juara umum pada SMP tersebut. Dimana proses yang dilakukan sangat cepat dan praktis dan obyektif karena perhitungannya dilakukan di dalam program.

Kata Kunci: Visual Basic, Sistem Pendukung Keputusan, SAW

\section{Pendahuluan}

Komputer merupakan perangkat keras yang keberadaannya tidak dapat lagi dielakkan, sehingga hampir semua aktifitas manusia secara sadar atau tidak telah terlibat, terkait dan tergantung pada komputer. Baik ketergantungan pada pencarian informasi, pengolahan data, hiburan maupun komputer sebagai alat pendukung bagi seorang pimpinan dalam menentukan kebijakan yang telah didasari oleh hasil pengolahan data dengan menggunakan komputer.

Terlebih lagi pada kasus penyelesaian masalah yang memiliki banyak kemungkinan untuk dipilih, maka sudah tentu komputer sangat dibutuhkan untuk membantu para pengambil kebijakan. Sebagai contoh, SMP Negeri 03 Kota Bengkulu merupakan sebuah lembaga pendidikan formal tingkat lanjutan yang syarat dengan berbagai permasalahan. Karena proses pendidikan dan pengajaran yang diselenggarakan oleh SMP Negeri 03 Kota Bengkulu harus mampu mencetak siswa yang memiliki kemampuan dan wawasan yang luas.

Sebagai sebuah lembaga pendidikan formal tingkat lanjutan pertama, SMP Negeri 03 Kota mencoba menerapkan semua aktifitas yang ada dengan berbasis komputer baik dalam hal penyusunan jadwal mata pelajaran, pembuatan laporan-laporan maupun aktifitas 
lain yang memerlukan keberadaan komputer sebagai alat bantu.

Salah satu masalah yang muncul setiap akhir tahun pelajaran adalah penentuan juara umum peringkat kelas siswa pada setiap kenaikan kelas. Karena menyangkut berbagai aspek yang dijadikan dasar pertimbangan bagi Kepala Sekolah. Hal itu dimaksudkan agar siswa juara umum yang telah ditentukan lebih obyektif karena dasar penilaiannya juga lebih obyektif.

Sedangkan metode yang digunakan pada konsep pengambilan keputusan tersebut adalah dengan metode Simple Additive Weighting (SAW).

Berdasarkan uraian latar belakang di atas maka penulis tertarik untuk mengangkat judul dalam penelitian yaitu "Sistem Pendukung Keputusan Dalam Pemilihan Juara Umum Pada Smp Negeri 3 Kota Bengkulu”.

\section{Tinjauan Pustaka}

\section{A. Pengertian Sistem Pendukung Keputusan}

Kusumadewi (2005:10), Sistem pendukung keputusan (SPK) adalah suatu sistem informasi berbasis komputer yang menghasilkan berbagai alternatif keputusan untuk membantu manajemen dalam menangani berbagai permasalahan yang terstruktur ataupun tidak terstruktur dengan menggunakan data dan model. Manfaat dari sistem pendukung keputusan adalah pengambilan keputusan yang tepat, sesuai dengan jenis keputusan yang diperlukan, membuat peramalan, membandingkan alternatif tindakan, membuat analisis dampak, serta membuat model.

Konsep sistem yang mendukung keputusan dikenal dengan istilah Management Decision Sistem. Sistem tersebut adalah suatu sistem yang berbasis komputer yang ditunjukan untuk membantu pengambilan keputusan dengan memanfaatkan data dan model tertentu untuk memecahkan berbagai persoalan yang tidak terstruktur. Sistem pendukung keputusan menyediakan informai pemecahan masalah maupun kemampuan dalam memecahkan masalah terstruktur dan semiterstruktur. Informasi yang dihasilkan adalah dalam bentuk periodik dan khusus dan output dari model matematik.

\section{B. SAW (Simple Additive Weighting)}

Metode SAW dapat memecahkan masalah kompleks, dimana kriteria yang diambil cukup banyak, struktur masalah yang belum jelas, ketidakpastian persepsi pembuat keputusan serta ketidakpastian tersedianya data statistik yang akurat.

Konsep dasar metode SAW ini adalah mencari penjumlahan terbobot dari rating kinerja pada setiap alternatif pada semua attribut. SAW membutuhkan proses normalisari matriks keputusan (X) ke suatu skala yang dapat diperbandingkan dengan semua rating alternatif yang ada.

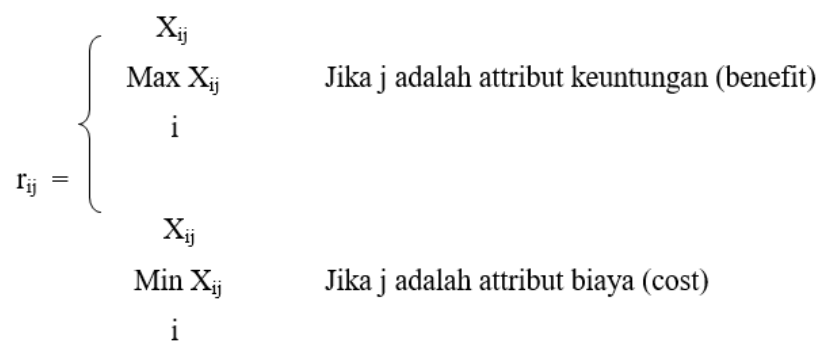

Keterangan :

$\mathbf{r}_{\mathrm{ij}} \quad=$ Nilai rating kinerja ternomalisasi

$\mathbf{x}_{\mathbf{i j}} \quad=$ Nilai atribut yang dimiliki dari setiap kriteria

$\operatorname{Max} \mathbf{x}_{\mathbf{i j}}=$ Nilai terbesar dari setiap kriteria

$\operatorname{Min} \mathbf{x}_{\mathbf{i j}}=$ Nilai terkecil dari setiap kriteria

Benefit = jika nilai terbesar adalah terbaik

Cost $=$ jika nilai terkecil adalah terbaik

Dimana rij adalah rating kinerja ternomalisasi dari alternative $A_{i}$ pada atribut $\mathrm{Cj} ; \mathrm{i}=1,2,$. .,m dan $\mathrm{j}=1,2, ., \mathrm{n}$. Nilai preferensi (yang paling utama) untuk setiap alternative $\left(\mathrm{V}_{\mathrm{i}}\right)$ diberikan sebagai :

$$
\mathbf{V}_{\mathrm{i}}=\sum_{\mathrm{j}=1}^{\mathbf{n}} \mathbf{W}_{\mathrm{j}} \mathbf{r}_{\mathrm{ij}}
$$

Keterangan :

$\mathrm{Vi}=$ rangking untuk setiap alternatif

$\mathrm{wj}=$ nilai bobot dari setiap kriteria

rij = nilai rating kinerja ternormalisasi

Nilai $V_{1}$ yang lebih besar mengindikasikan bahwa alternative $A_{i}$ lebih terpilih.

Adapun langkah-langkah penyelesaian Simple Additive Weigthing (SAW)adalah : 
1. Menentukan Kriteria apa saja yang akan dijadikan acuan dalam pengambilan keputusan, yaitu :

$\mathrm{C} 1=$ Rata-rata Nilai Raport

$\mathrm{C} 2=$ Prestasi Bidang Olah Raga

C3 = Prestasi Bidang Seni dan Cerdas Cermat

C4 = Keikut-Sertaan Kegiatan Ekstra Kurikuler

C5 = Etika Di Sekolah

Setelah membuat matriks berdasarkan kriteria $\left(\mathrm{C}_{1}, \mathrm{C}_{2}, \mathrm{C}_{3}, \ldots, \mathrm{C}_{\mathrm{J}}\right)$, kemudian melakukan normalisasi matriks berdasarkan persamaan yang disesuaikan dengan jenis atribut (aribut keuntungan ataupun atribut biaya), sehingga matriks ternormalisasi $\mathrm{R}$

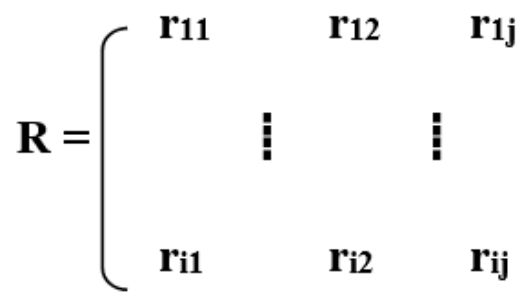

2. Menentukan rating kecocokan setiap alternatif pada setiap kriteria :

- $\quad$ Nilai 1 = Sangat Kurang (SK)

- $\quad$ Nilai 2 = Kurang $(\mathrm{K})$

- $\quad$ Nilai 3 = Cukup $(\mathrm{C})$

- $\quad$ Nilai $4=$ Baik (B)

- $\quad$ Nilai $5=$ Terbaik $(\mathrm{TB})$

memberikan bobot preferensi (W)

3. Hasil akhir diperoleh dari proses perankingan yaitu penjumlahan dari perkalian matriks ternormalisasi $\mathrm{R}$ dengan vektor bobot preferensi, sehingga diperoleh nilai terbesar yang dipilih sebagai alternatif terbaik misalnya (A1) sebagai solusi.

\section{Konsep Perancangan Database}

Nugroho (2005:67) mengungkapkan bahwa Data Base (basis data) adalah sebuah cara mendokumentasikan berbagai macam data yang kemudian dimanajemen dengan sebuah system untuk kemudian disimpan dalam sebuah media penyimpanan. Adapun ciri-ciri basis data diantaranya adalah :

1. Efisiensi meliputi kecepatan, ukuran, dan ketepatan
2. Data dalam jumlah besar.

3. Berbagi Pakai (dipakai bersama sama/Sharebility).

4. Mengurangi bahkan menghilangkan terjadinya duplikasi dan ketidakkonsistenan data

\section{1) DFD (Data Flow Diagram)}

DFD (data flow diagram) merupakan diagram yang menggunakan notasi-notasi untuk menggambarkan arus dari data sistem. (Jogianto, $2005: 700$ ).

DFD (data flow diagram) sering digunakan untuk menggambarkan suatu system yang telah ada atau system baru yang akan dikembangkan secara logika tanpa mempertimbangkan lingkungan fisik dimana data tersebut mengalir (misalnya lewat telepon) atau lingkungan fisik tersebut akan disimpan.

\section{2) ERD (Entity Relationship Diagram)}

Model keterhubungan entitas yang berisikan komponen-komponen himpunan entitas dan himpunan relasi yang masing-masing dilengkapi dengan atribut untuk mempresentasikan seluruh fakta yang digambarkan dengan sistematis dalam bentuk diagram. Ere digunakan untuk menggambarkan hubungan antar penyimpanan/data store yang terdapat di DFD.

\section{3) Flowchart}

Flowchart atau Bagan alir adalah bagan (Chart) yang menunjukan alir (flow) di dalam program atau prosedur sistem secara logika. (Jogianto, 2005 : 795). Bagan alir digunakan untuk alat bantu komunikasi dan untuk dokumentasi.

\section{Metodologi Penelitian}

\section{A. Metode Penelitian}

Metode yang dilakukan dalam penelitian ini adalah pengembangan sistem baru, yaitu menyusun suatu sistem baru untuk mengantikan sistem yang lama secara menyeluruh atau menyempurnakan sistem yang telah ada berjalan. Ada beberapa target yang ingin dicapai engembangkan sistem baru yaitu, kinerja meningkat, informasi semakin akurat dan tepat waktu, efesiensi waktu dan ekonomis. 


\section{B. Metode Pengumpulan Data}

1. Studi Pustaka, dimana data dan informasi yang diperlukan didapatkan melalui sumber pustaka seperti Peraturan Pemerintah, Surat-surat Keputusan, Buku pedoman tentang pendidikan yang ada pada SMP Negeri 03 Kota Bengkulu.

2. Wawancara, merupakan salah satu cara mendapatkan gambaran informasi dari pihak SMP Negeri 03 Kota Bengkulu.

3. Implementasi program untuk mendapatkan faktafakta sebagai akibat dari uji coba program yang akan dibangun nantinya.

\section{Metode Perancangan Sistem}

\section{1) Analisa Sistem Aktual}

Dalam pemilihan juara umum pada setiap tingkat dilakukan oleh SMP Negeri 03 Kota Bengkulu adalah dengan cara membaca kembali rekaman-rekaman rapor siswa.

Selanjutnya setelah nilai raport tiap kelas paralel diperbandingkan, rapat wali kelas memutuskan seorang siswa untuk ditunjuk sebagai juara umum. Sedangkan kriteria juara umum yang ada tidaklah hanya berdasarkan nilai rapor siswa dari semester ganjil dan semester genap saja. Tetapi banyak aspek yang dapat dijadikan dasar pertimbangan dalam memutuskan siapa yang layak mendapat prestasi sebagai juara umum. Hal itu jelas menimbulkan permasalahan apabila terjadi rata-rata nilai rapor siswa pada kelas paralel terjadi kesamaan, sedangkan juara umum yang ditunjuk harus satu orang.

\section{2) Analisa Sistem Baru}

Pengembangan sebuah sistem baru perlu dilakukan dengan maksud untuk memperbaiki sistem yang telah berlaku selama ini. Untuk mendapatkan hasil yang lebih baik dengan mengikuti pola pembangunan sebuah perangkat lunak yang dibangun sendiri dengan memenuhi kaidah-kaidah, teori-teori dan aturan-aturan yang ada.

Contoh perhitungan misalkan :

$\mathrm{C}_{1}$ : kriteria rata-rata nilai raport, dengan skala nilai sebagai berikut :

5 : rata-rata raport $9-10$
4 : rata-rata raport $8-8,9$

3 : rata-rata raport $7-7,9$

2 : rata-rata raport $6-6,9$

1 : rata-rata raport $<6$

$\mathrm{C}_{2}$ : kriteria prestasi bidang olah raga, dengan skala nilai sebagai berikut :

5 : pernah mendapat juara pada tingkat Internasional

4 : pernah mendapat juara pada tingkat Nasional

3 : pernah mendapat juara pada tingkat Provinsi

2 : pernah mendapat juara pada tingkat Kota

1 : pernah mendapat juara pada kejuaraan antar kelas

$\mathrm{C}_{3}$ : kriteria prestasi bidang seni dan cerdas cermat, dengan skala nilai sebagai berikut :

5 : pernah mendapat juara pada tingkat Internasional

4 : pernah mendapat juara pada tingkat Nasional

3 : pernah mendapat juara pada tingkat Provinsi

$2:$ pernah mendapat juara pada tingkat Kota

1 : pernah mendapat juara pada kejuaraan antar kelas

$\mathrm{C}_{4}$ : kriteria keikut-sertaan kegiatan ekstra kurikuler, dengan skala nilai sebagai berikut :

5 : Sangat aktif mengikuti berbagai kegiatan Ekstra Kurkikuler

4 : Aktif mengikuti berbagai kegiatan Ekstra Kurkikuler

3 : Cukup aktif mengikuti berbagai kegiatan Ekstra Kurkikuler

2 : Kurang aktif mengikuti berbagai kegiatan Ekstra Kurkikuler

1 : Tidak aktif mengikuti berbagai kegiatan Ekstra Kurkikuler

$\mathrm{C}_{5}$ : kriteria etika di sekolah, dengan skala nilai sebagai berikut :

5 : Sangat menjunjung kesopanan dan etika

4 : Menjunjung kesopanan dan etika

3 : Cukup menjunjung kesopanan dan etika

2 : Agak menjunjung kesopanan dan etika

1 : Kurang menjunjung kesopanan dan etika

\begin{tabular}{|c|c|c|c|c|c|}
\hline \multirow{2}{*}{ Alternatif } & \multicolumn{5}{|c|}{ Kriteria } \\
\cline { 2 - 6 } & $\mathrm{C}_{1}$ & $\mathrm{C}_{2}$ & $\mathrm{C}_{3}$ & $\mathrm{C}_{4}$ & $\mathrm{C}_{5}$ \\
\hline $\mathrm{A}_{1}$ & 3 & 4 & 5 & 3 & 3 \\
\hline $\mathrm{A}_{2}$ & 2 & 3 & 5 & 2 & 3 \\
\hline $\mathrm{A}_{3}$ & 3 & 4 & 2 & 3 & 2 \\
\hline $\mathrm{A}_{4}$ & 3 & 4 & 3 & 3 & 3 \\
\hline $\mathrm{A}_{5}$ & 2 & 3 & 4 & 3 & 3 \\
\hline
\end{tabular}


Karena setiap nilai yang diberikan pada setiap alternatif di setiap kriteria merupakan nilai kecocokan (nilai terbesar adalah terbaik), maka semua kriteria yang diberikan diasumsikan sebagai kriteria keuntungan. Pengambil keputusan memberikan bobot berdasarkan tingkat kepentingan masing-masing kriteria yang dibutuhkan sebagai berikut :

Bobot Preferensi : $W=\{2,4,4,4,3\}$

Selanjutnya adalah membuat matriks keputusan $X$, dibuat dari tabel kecocokan sebagai berikut ini :

Selanjutnya dilakukan perhitungan matriks keputusan ternormalisasi dengan cara sebagai berikut :

$\mathrm{X}=\left\{\begin{array}{lllll}3 & 4 & 5 & 3 & 3 \\ 2 & 3 & 5 & 2 & 3 \\ 3 & 4 & 2 & 3 & 2 \\ 3 & 4 & 3 & 3 & 3 \\ 2 & 3 & 4 & 3 & 3\end{array}\right\}$

Pertama, dilakukan normalisasi matriks $\mathrm{X}$ untuk menghitung nilai masing-masing kriteria berdasarkan kriteria diasumsikan sebagai kriteria keuntungan atau biaya sebagai berikut :

$$
\begin{aligned}
& \mathbf{r}_{11}=\frac{3}{\max \{3 ; 2 ; 3 ; 3 ; 2\}}=\frac{3}{3}=1 \\
& \mathbf{r}_{21}=\frac{2}{\max \{3 ; 2 ; 3 ; 3 ; 2\}}=\frac{2}{3}=0,67 \\
& \mathbf{r}_{31}=\frac{\max \{3 ; 2 ; 3 ; 3 ; 2\}}{\mathbf{r}_{41}=}=\frac{3}{3}=1 \\
& \mathbf{r}_{51}=\frac{\max \{3 ; 2 ; 3 ; 3 ; 2\}}{\max \{3 ; 2 ; 3 ; 3 ; 2\}}=\frac{3}{2}=1 \\
& \frac{3}{3}
\end{aligned}
$$

$$
\begin{gathered}
\mathbf{r}_{41}=\frac{3}{\max \{3 ; 2 ; 3 ; 3 ; 2\}}=\frac{3}{3}=1 \\
\mathbf{r}_{51}=\frac{2}{\max \{3 ; 2 ; 3 ; 3 ; 2\}}=\frac{2}{3}=0,67
\end{gathered}
$$$$
\mathbf{r}_{22}=\frac{3}{\max \{4 ; 3 ; 4 ; 4 ; 3\}}=\frac{3}{4}=0,75
$$$$
r_{32}=\frac{4}{\max \{4 ; 3 ; 4 ; 4 ; 3\}}=\frac{4}{4}=1
$$$$
\mathbf{r}_{42}=\frac{4}{\max \{4 ; 3 ; 4 ; 4 ; 3\}}=\frac{4}{4}=1
$$$$
\mathbf{r}_{52}=\frac{3}{\max \{4 ; 3 ; 4 ; 4 ; 3\}}=\frac{3}{4}=0,75
$$$$
\mathbf{r}_{13}=\frac{5}{\max \{5 ; 5 ; 2 ; 3 ; 4\}}=\frac{5}{5}=1
$$$$
\mathbf{r}_{23}=\frac{5}{\max \{5 ; 5 ; 2 ; 3 ; 4\}}=\frac{5}{5}=1
$$$$
\mathbf{r}_{33}=\frac{2}{\max \{5 ; 5 ; 2 ; 3 ; 4\}}=\frac{2}{5}=0,4
$$$$
\mathbf{r}_{43}=\frac{3}{\max \{5 ; 5 ; 2 ; 3 ; 4\}}=\frac{3}{5}=0,6
$$$$
\mathbf{r}_{53}=\frac{4}{\max \{5 ; 5 ; 2 ; 3 ; 4\}}=\frac{4}{5}=0,8
$$$$
\mathbf{r}_{14}=\frac{3}{\max \{3 ; 2 ; 3 ; 3 ; 3\}}=\frac{3}{3}=1
$$ 


$$
r_{24}=\frac{2}{\max \{3 ; 2 ; 3 ; 3 ; 3\}}=\frac{2}{3}=0,67
$$$$
\mathrm{r}_{34}=\frac{3}{\max \{3 ; 2 ; 3 ; 3 ; 3\}}=\frac{3}{3}=1
$$$$
\mathrm{r}_{44}=\frac{3}{\max \{3 ; 2 ; 3 ; 3 ; 3\}}=\frac{3}{3}=1
$$$$
r_{54}=\frac{3}{\max \{3 ; 2 ; 3 ; 3 ; 3\}}=\frac{3}{3}=1
$$$$
\begin{aligned}
& \mathbf{r}_{15}=\frac{3}{\max \{3 ; 3 ; 2 ; 3 ; 3\}}=\frac{3}{3}=1 \\
& r_{25}=\frac{2}{\max \{3 ; 3 ; 2 ; 3 ; 3\}}=\frac{3}{3}=1
\end{aligned}
$$$$
\mathbf{r}_{35}=\frac{2}{\max \{3 ; 3 ; 2 ; 3 ; 3\}}=\frac{2}{3}=0,67
$$$$
r_{45}=\frac{3}{\max \{3 ; 3 ; 2 ; 3 ; 3\}}=\frac{3}{3}=1
$$$$
r_{55}=\frac{3}{\max \{3 ; 3 ; 2 ; 3 ; 3\}}=\frac{3}{3}=1
$$

Dengan matriks R ssebagai berikut :

$$
R=\left(\begin{array}{lllll}
1 & 1 & 1 & 1 & 1 \\
0,67 & 0,75 & 1 & 0,67 & 1 \\
1 & 1 & 0,4 & 1 & 0,67 \\
1 & 1 & 0,6 & 1 & 1 \\
0,67 & 0,75 & 0,8 & 1 & 1
\end{array}\right)
$$

Selanjutnya matriks hasil normalisasi R dikalikan dengan matriks bobot preferensi yang telah ditentukan yakni : $\mathrm{W}=\{\mathbf{2}, \mathbf{4}, \mathbf{4}, \mathbf{4}, \mathbf{3}\} \quad$ dan diperoleh matriks $\mathrm{Y}$ sebagai berikut :

$$
\mathbf{V}_{\mathrm{i}}=\sum_{\mathrm{j}=1}^{\mathbf{n}} \mathbf{W}_{\mathrm{j}} \mathrm{r}_{\mathrm{ij}}
$$

$$
\begin{aligned}
& \mathrm{V}_{1}=(2)(1)+(4)(1)+(4)(1)+(4)(1)+(3)(1)=17 \\
& \mathrm{~V}_{2}=(2)(0,67)+(4)(0,75)+(4)(1)+(4)(0,67)+(3)(1)=
\end{aligned}
$$

14

$$
\begin{aligned}
& \mathrm{V}_{3}=(2)(1)+(4)(1)+(4)(0,4)+(4)(1)+(3)(0,67)=13,61 \\
& \mathrm{~V}_{4}=(2)(1)+(4)(1)+(4)(0,6)+(4)(1)+(3)(1)=15,4 \\
& V_{5}=(2)(0,67)+(4)(0,75)+(4)(0,8)+(4)(1)+(3)(1)= \\
& 14,54
\end{aligned}
$$

Hasil perangkingan diperoleh $: \mathrm{V}_{1}=17 ; \mathrm{V}_{2}=14 ; \mathrm{V}_{3}=$ 13,$61 ; V_{4}=15,4 ; V_{5}=14,54$

Dengan demikian nilai terbaik ada pada $\mathbf{V}_{\mathbf{1}}$ dengan alternatif A1 adalah alternatif yang terpilih sebagai alternatif terbaik untuk terpilih sebagai juara umum.

\section{4) Diagram Konteks (Context Diagram)}

Diagram konteks adalah merupakan cara penggambaran hubungan antara kesatuan luar (source) terhadap sistem pendukung keputusan. Adapun diagram konteks dimaksud adalah sebagaimana gambar 1.

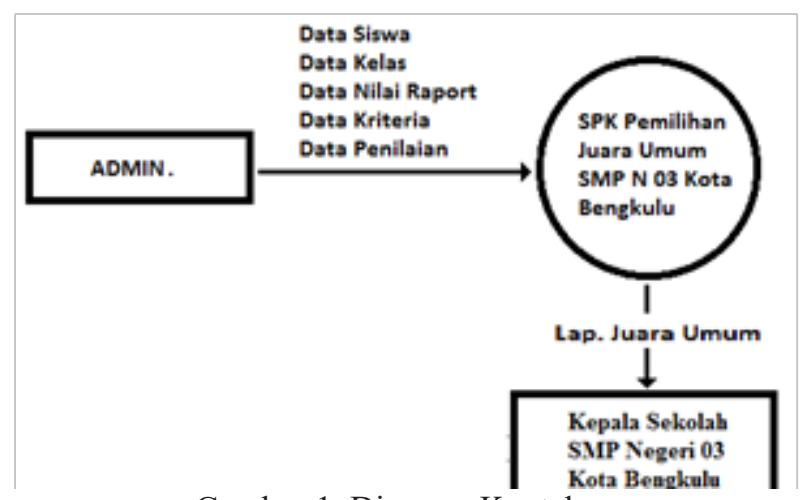

Gambar 1. Diagram Konteks

\section{5) ERD (Entity Relationship Diagram)}

Untuk dapat mengetahui tingkat keterkaitan antar entitas yang ada di dalam sistem pengambilan keputusan penentuan juara umum pada SMP Negeri 03 Kota Bengkulu, perlu adanya deskripsi keterkaitan tersebut.

Adapun bentuk diagram keterkaitan antar entitas (Entity Relationship Diagram) atau ERD dapat dilihat pada gambar 2 . 


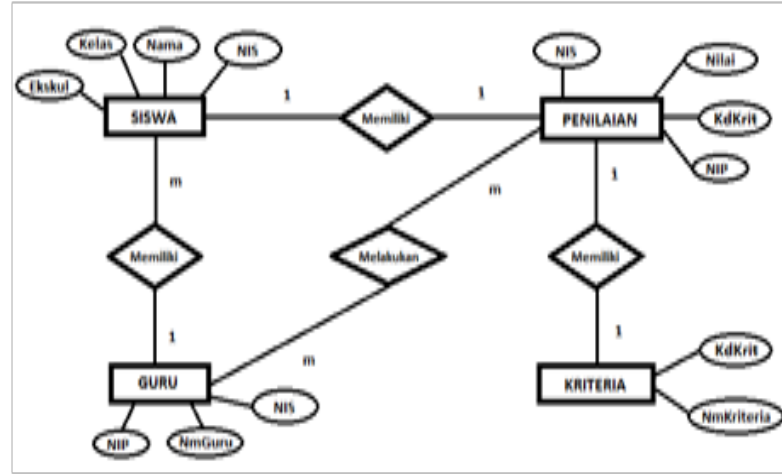

Gambar 2. Entity Relationship Diagram (ERD)

6) Rancangan File

1. File Data Administrator

Nama Tabel: Administrator.MDB

Primary Key : -

Foreign Key : -

\begin{tabular}{|c|l|c|c|c|}
\hline No. & Nama Field & Tipe & Ukuran & Keterangan \\
\hline 1. & NmAdmin & Text & 10 & Nama Admin. \\
\hline 2. & Password & Text & 5 & Password \\
\hline
\end{tabular}

2. File Data Siswa

Nama Tabel : Siswa

Primary Key : NIS

Foreign Key : -

\begin{tabular}{|c|l|c|c|l|}
\hline No. & Nama Field & Tipe & Ukuran & \multicolumn{1}{|c|}{ Keterangan } \\
\hline 1. & NIS & Text & 6 & No Induk Siswa \\
\hline 2. & NamSis & Text & 25 & Nama Siswa \\
\hline 3. & Kelas & Text & 4 & Kelas \\
\hline 4. & JnsKel & Text & 9 & Jenis Kelamin \\
\hline
\end{tabular}

3. File Data Guru

Nama Tabel : Guru

Primary Key : NIP

Foreign Key : NIS

\begin{tabular}{|c|l|c|c|l|}
\hline No. & Nama Field & Tipe & Ukuran & \multicolumn{1}{|c|}{ Keterangan } \\
\hline 1. & NIP & Text & 17 & NIP Guru \\
\hline 2. & NmGuru & Text & 25 & Nama Guru \\
\hline 3. & Jabatan & Text & 25 & Jabatan Guru \\
\hline 4. & NIS & Text & 6 & No Induk Siswa \\
\hline 5. & Nama & Text & 25 & Nama Siswa \\
\hline
\end{tabular}

4. File Data Kriteria

Nama Tabel : Kriteria

Primary Key : KdKriteria

Foreign Key : -

\begin{tabular}{|c|c|c|c|l|}
\hline No. & Nama Field & Tipe & Ukuran & Keterangan \\
\hline 1. & KdKriteria & Text & 2 & $\begin{array}{l}\text { Kode } \\
\text { Kriteria }\end{array}$ \\
\hline 2. & NmKriteria & Text & 25 & $\begin{array}{l}\text { Nama } \\
\text { Kriteria }\end{array}$ \\
\hline
\end{tabular}

5. File Data Penilaian

Nama Tabel : Penilaian

Primary Key : KdKriteria, NIS,

Foreign Key : -

\begin{tabular}{|c|l|c|c|l|}
\hline No. & Nama Field & Tipe & Ukuran & \multicolumn{1}{|c|}{ Keterangan } \\
\hline 1. & KdKriteria & Text & 2 & Kode Kriteria \\
\hline 2. & NmKriteria & Text & 25 & Nama Kriteria \\
\hline 3. & NIS & Text & 6 & $\begin{array}{l}\text { No Induk } \\
\text { Siswa }\end{array}$ \\
\hline 4. & Nama & Text & 25 & Nama Siswa \\
\hline 5. & Nilai & Integer & - & Nilai \\
\hline 6. & NIP & Text & 6 & $\begin{array}{l}\text { No Induk } \\
\text { Pegawai }\end{array}$ \\
\hline 7. & NmGuru & Text & 25 & Nama Guru \\
\hline
\end{tabular}

7) Rancangan Struktur Menu

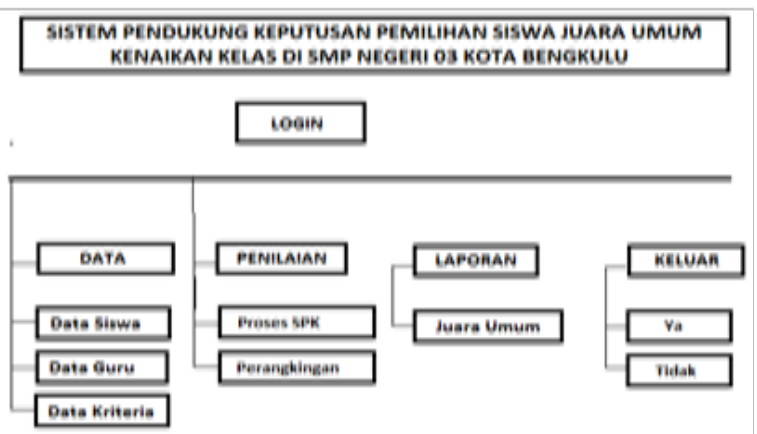

Gambar 3. Struktur Menu

8) Rancangan Menu

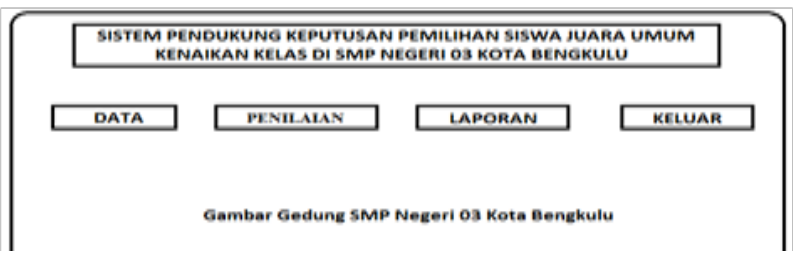

Gambar 4. Menu SPK Juara Umum

9) Rancangan Input

1. Rancangan Input Data Login

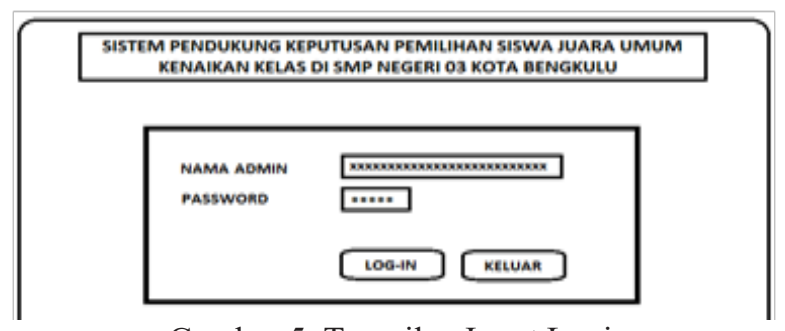

Gambar 5. Tampilan Input Login

2. Rancangan Input Data Siswa 


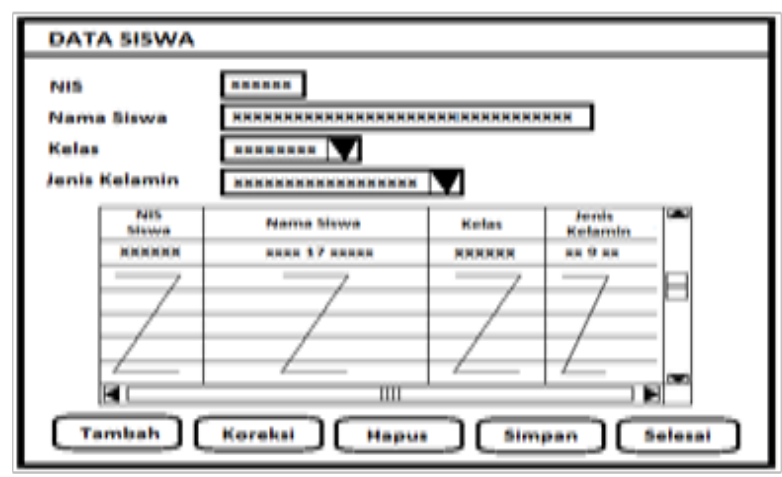

Gambar 6. Tampilan Input Data Siswa

3. Rancangan Input Data Guru

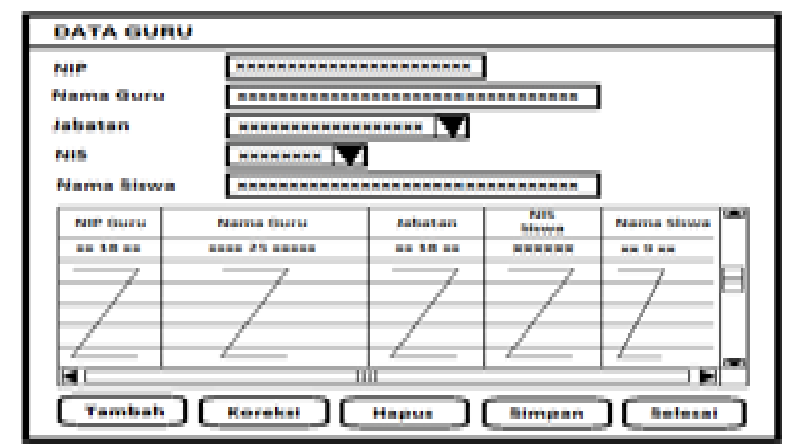

Gambar 7. Tampilan Input Data Guru

4. Rancangan Input Data Kriteria

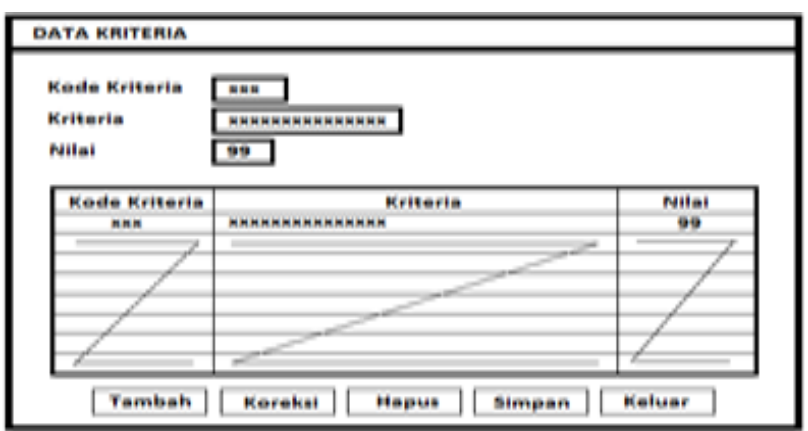

Gambar 8. Tampilan Input Data Kriteria

5. Rancangan Input Penilaian

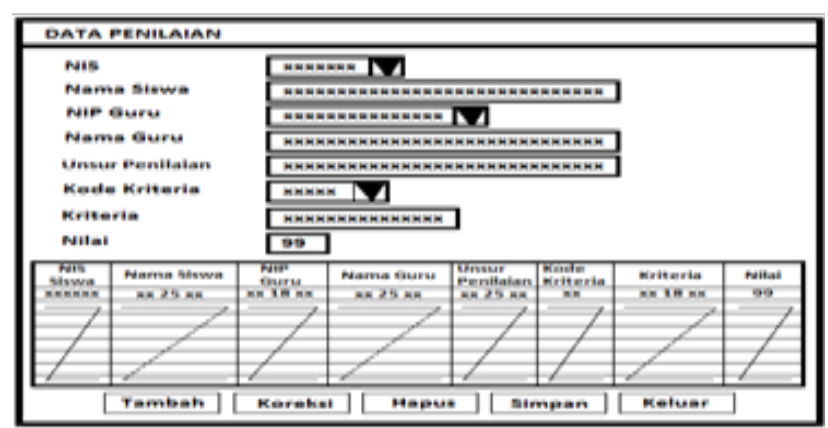

Gambar 9. Tampilan Input Penilaian

\section{0) Rancangan Output}

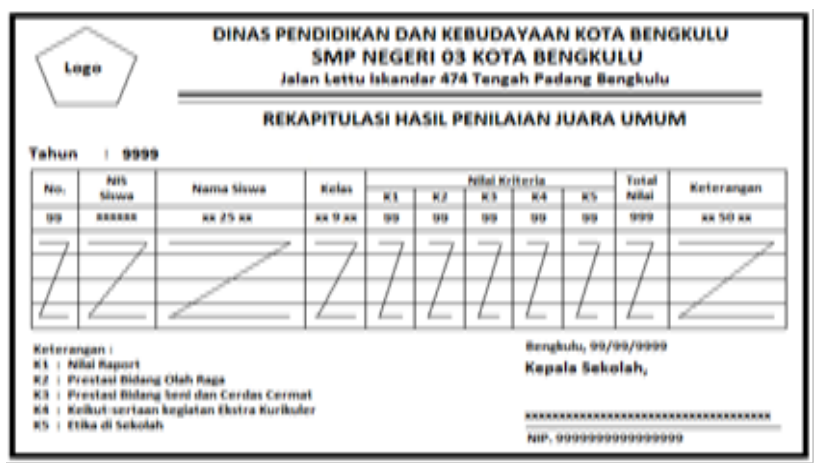

Gambar 10. Rancangan Output Hasil Penilaian

\section{Metode Perancangan Pengujian}

Setelah selesai dibangun, selanjutnya dilakukan pengujian untuk mendapatkan kepastian terhadap program yang telah dibangun. Pengujian terhadap program nantinya akan dilakasnakan dalam dua metode, yakni :

1. Metode Black Box, yakni pengujian yang memfokuskan pada algoritma program. Dengan demikian pengujian dengan metode black box ini bertujuan untuk mendapatkan kesalahan karena fungsi-fungsi, prosedur-prosedur dan variabelvariabel yang hilang (fungsi, prosedur, variabel yang seharusnya ada)

2. Metode White Box, yakni pengujian yang memfokuskan pada keperluan fungsional dari software. Karena itu pengujian dengan metode white box memungkinkan pengembang software untuk menelaah perfoma, interface dan integritas dari program. Dengan demikian pengujian dengan metode whitebox ini bertujuan untuk mendapatkan kesalahan karena rangkaian class dan module, serta fungsi-fungsi, prosedur-prosedur dan variabelvariabel yang terangkai.

\section{Pembahasan}

\section{A. Hasil dan Pembahasan Program}

Program sistem pendukung keputusan pemilihan juara umum pada SMP Negeri 3 Kota Bengkulu ini diberi nama SPKSiswa. Dimana program ini dapat diaktifkan melalui Run maupun Explore karena file tersebut telah berbentuk sebagai file Aplikasi. Sedangkan source programnya baru dapat diaktifkan apabila pada komputer telah terpasang MicroSoft Visual Basic 60. 
Adapun apabila program tersebut diaktifkan, maka pertama kali pada layar akan terlihat tampilan program seperti terlihat pada gambar 11 .

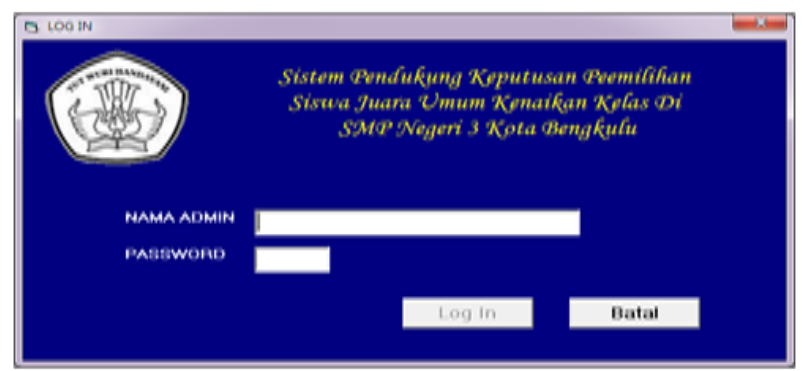

Gambar 11. Tampilan Menu Awal

Berdasarkan gambar 11 dapat diamati bahwa, program tersebut melakukan pembatasan penggunaan dengan cara meminta nama admin dan password. Hal itu dimaksudkan agar program tersebut tidak bebas dibuka oleh orang yang tidak memiliki akun yang benar, setelah admin memasukan usernam dan pasword maka tampil gambar seperti dibawah ini Data dan Laporan

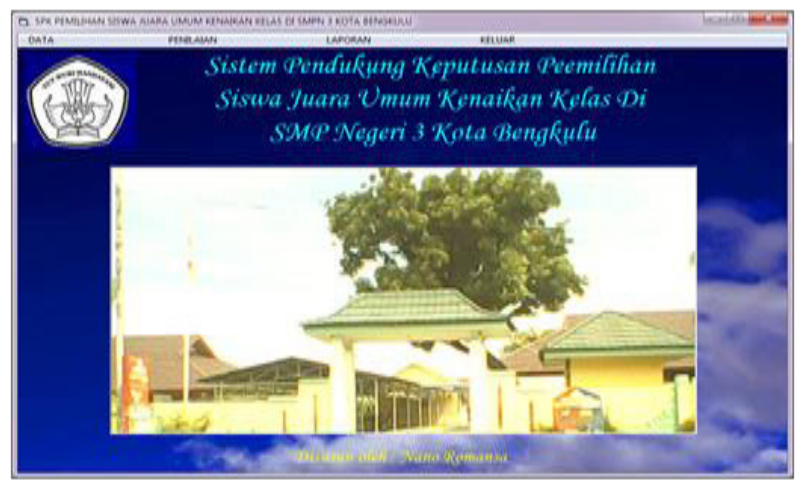

Gambar 12. Tampilan Sub Menu Utama

Berdasarkan pada tampilan gambar 12, dapat dipahami bahwa menu utama tersebut memiliki tiga macam menu, yakni Data, Penilain, Laporan dan Keluar. Menu Data disediakan untuk melakukan pengelolaan terhadap data-data dasar yang akan digunakan. Menu Laporan disediakan untuk melayani pembuatan laporan, sedangkan menu Keluar disediakan apabila pengguna akan keluar dari program. Kemudian tampillan layarnya seperti terlihat pada gambar 13 .

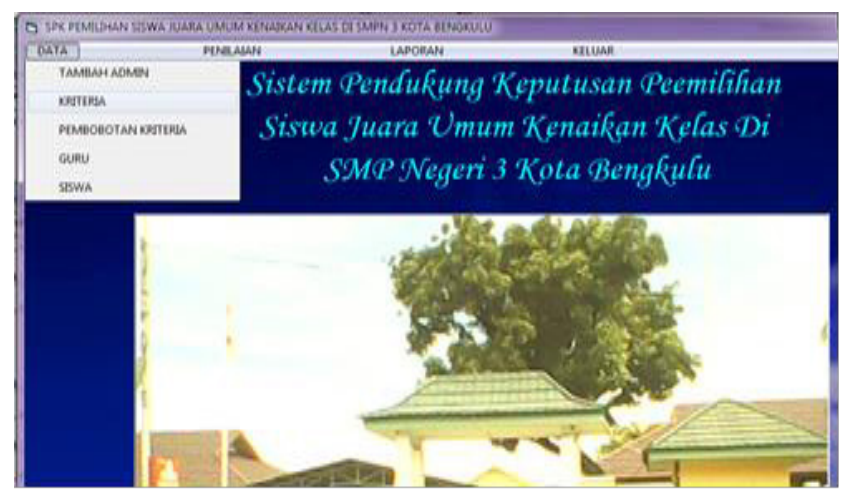

Gambar 13. Tampilan Sub Menu Data

Adapun tampilan dari form Tambah Admin tersebut dapat dilihat seperti pada gambar 14 .

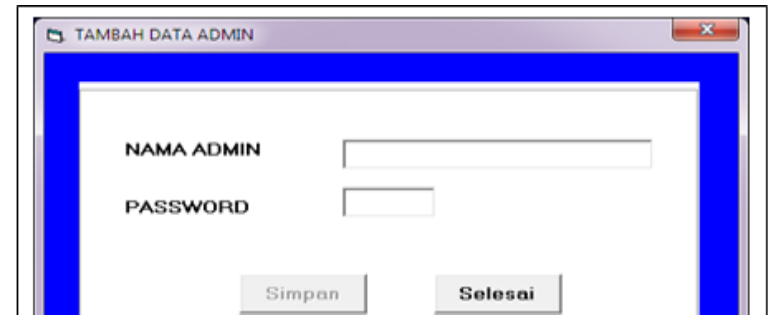

Gambar 14. Tampilan Tambah Data Admin

Berdasarkan tampilan pada gambar 14 di atas, dapat dijelaskan bahwa formulir tersebut berfungsi sebagai tatap muka (interface) guna melakukan penambahan data admin

\section{a. Form Data Kriteria}

Data Kriteria, maka pada layar akan terlihat tampilan seperti gambar 15.

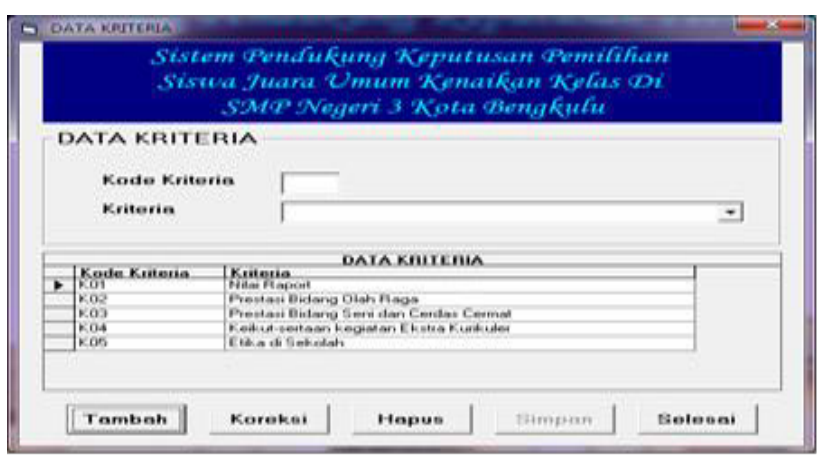

Gambar 15. Tampilan Form Data Kriteria

b. Form Data Siswa

Tampilan untuk menampilkan Formulir Data Siswa, maka pada layar akan terlihat tampilan gambar 16 . 


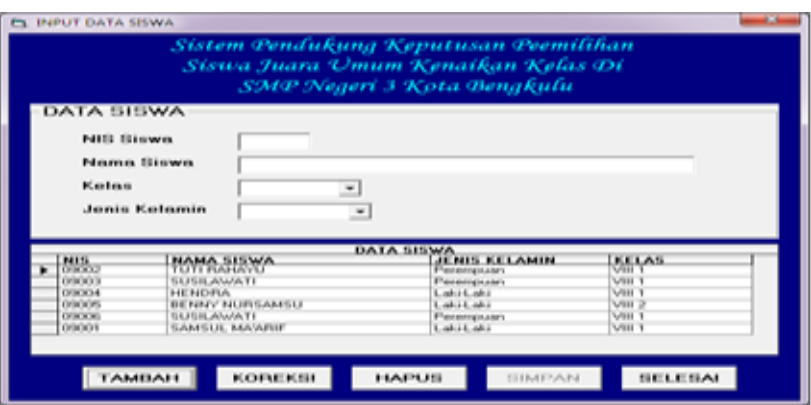

Gambar 16. Tampilan Form Data Siswa

\section{c. Form Data Guru}

Data Pesanan disediakan guna melayani pengelolaan bagi data guru, dengan demikian diharapkan nantinya program ini dapat mengelola data guru dengan baik. Untuk menampilkan Formulir Data Guru, maka pada layar akan terlihat tampilan seperti gambar 17.

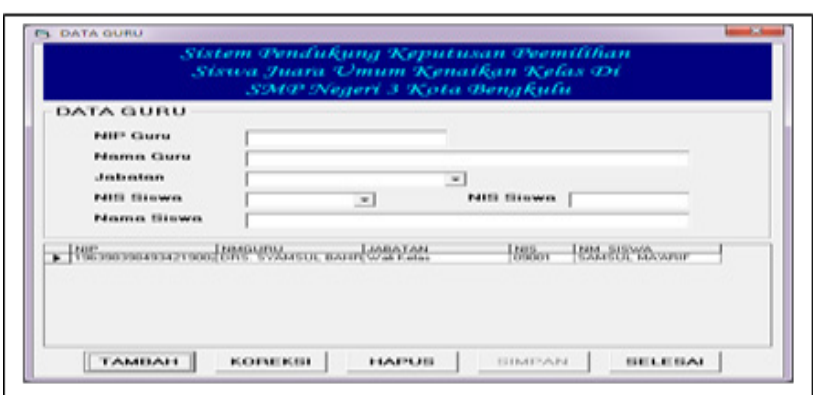

Gambar 17. Tampilan Form Data Guru

\section{d. Laporan}

Submenu laporan ini disediakan untuk melayani pengguna dalam upayanya menampilkan laporan hasil pengolahan data yang telah dilakukan pada sub menu data.

Adapun macam-macam bentuk laporan yang dimaksud dapat dijelaskan tampilan hasilnya laporan terlihat pada gambar 18 dibawah ini.
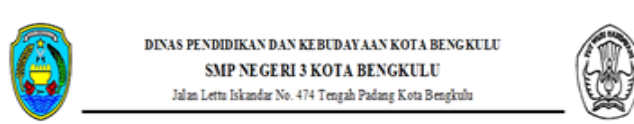

REKAPITULASI HASIL PENILAIAN JUARA TMUM KE NAIKAN KELLAS

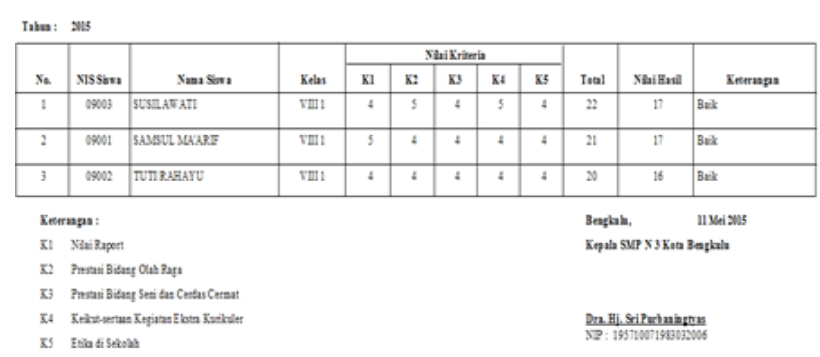

Gambar 18. Tampilan Output Rekap. Hasil Penilaian Juara Umum Kenaikan Kelas

\section{B. Pengujian Sistem}

Adapun tahap pengujian sistem baru yang dilaksanakan pada SMP Negeri 03 Kota Bengkulu secara umum telah sesuai dengan kebutuhan yang diinginkan oleh sekolah karena banyak memberikan kemudahan dalam hal pengoperasioan program.

Berdasarkan data hasil kuisioner, dapat dicari prosentase masing-masing jawaban dengan menggunakan rumus : $\mathrm{Y}=(\mathrm{P} / \mathrm{Q})^{*} 100 \%$.

Keterangan :

$\mathrm{P}=$ Banyaknya jawaban tiap pertanyaan

$\mathrm{Q}=$ Jumlah responden

$\mathrm{Y}=$ Nilai persentase

Jawaban pengisi kuisioner tentang pertanyaanpertanyaan yang diajukan adalah :

1. Apakah aplikasi yang telah dibuat ini mudah dalam penggunaannya?

\begin{tabular}{|l|c|c|}
\hline \multicolumn{1}{|c|}{ Jawaban } & $\begin{array}{c}\text { Jumlah } \\
\text { Responden }\end{array}$ & Persentase \\
\hline $\begin{array}{l}\text { Sangat mudah } \\
\text { digunakan }\end{array}$ & - & $0 \%$ \\
\hline Mudah digunakan & 1 & $100 \%$ \\
\hline Cukup sulit digunakan & - & $0 \%$ \\
\hline Sulit digunakan & - & $0 \%$ \\
\hline
\end{tabular}

2. Apakah aplikasi yang telah dibuat ini mudah untuk dipelajari.?

\begin{tabular}{|l|c|c|}
\hline \multicolumn{1}{|c|}{ Jawaban } & $\begin{array}{c}\text { Jumlah } \\
\text { Responden }\end{array}$ & Persentase \\
\hline $\begin{array}{l}\text { Sangat mudah } \\
\text { dipelajari }\end{array}$ & - & $0 \%$ \\
\hline Mudah dipelajari & 1 & $100 \%$ \\
\hline Sulit dipelajari & - & $0 \%$ \\
\hline Biasa saja & - & $0 \%$ \\
\hline
\end{tabular}

3. Apakah Tampilan dari program aplikasi ini terlihat menarik.?

\begin{tabular}{|l|c|c|}
\hline \multicolumn{1}{|c|}{ Jawaban } & $\begin{array}{c}\text { Jumlah } \\
\text { Responden }\end{array}$ & Persentase \\
\hline Sangat Menarik & - & $0 \%$ \\
\hline Menarik & 1 & $100 \%$ \\
\hline $\begin{array}{l}\text { Kurang } \\
\text { Menarik }\end{array}$ & - & $0 \%$ \\
\hline Biasa saja & - & $0 \%$ \\
\hline
\end{tabular}

4. Apakah aplikasi ini dapat membantu dalam penerbitan surat keterangan hasil pemakaian program.? 


\begin{tabular}{|l|c|c|}
\hline \multicolumn{1}{|c|}{ Jawaban } & $\begin{array}{c}\text { Jumlah } \\
\text { responden }\end{array}$ & Persentase \\
\hline $\begin{array}{l}\text { Sangat } \\
\text { membantu }\end{array}$ & - & $0 \%$ \\
\hline Membantu & 1 & $100 \%$ \\
\hline $\begin{array}{l}\text { Kurang } \\
\text { Membantu }\end{array}$ & - & $0 \%$ \\
\hline Tidak membantu & - & $0 \%$ \\
\hline
\end{tabular}

5. Apakah data faktor pengujian pada aplikasi ini sesuai dengan ketentuan.yang diinginkan oleh pihak sekolah?

\begin{tabular}{|l|c|c|}
\hline \multicolumn{1}{|c|}{ Jawaban } & $\begin{array}{c}\text { Jumlah } \\
\text { Responden }\end{array}$ & Persentase \\
\hline Sangat sesuai & - & $0 \%$ \\
\hline Sesuai & 1 & $100 \%$ \\
\hline Kurang Sesuai & - & $0 \%$ \\
\hline Tidak sesuai & - & $0 \%$ \\
\hline
\end{tabular}

6. Apakah hasil kesimpulan dan informasi aplikasi ini akurat.?

\begin{tabular}{|l|c|c|}
\hline \multicolumn{1}{|c|}{ Jawaban } & $\begin{array}{c}\text { Jumlah } \\
\text { Responden }\end{array}$ & Persentase \\
\hline Akurat & - & $0 \%$ \\
\hline Cukup akurat & 1 & $100 \%$ \\
\hline Kurang akurat & - & $0 \%$ \\
\hline Tidak Akurat & - & $0 \%$ \\
\hline
\end{tabular}

Dari data diatas dapat di simpulkan dengan menggunakan grafik hasil pengujian seperti di bawah ini :

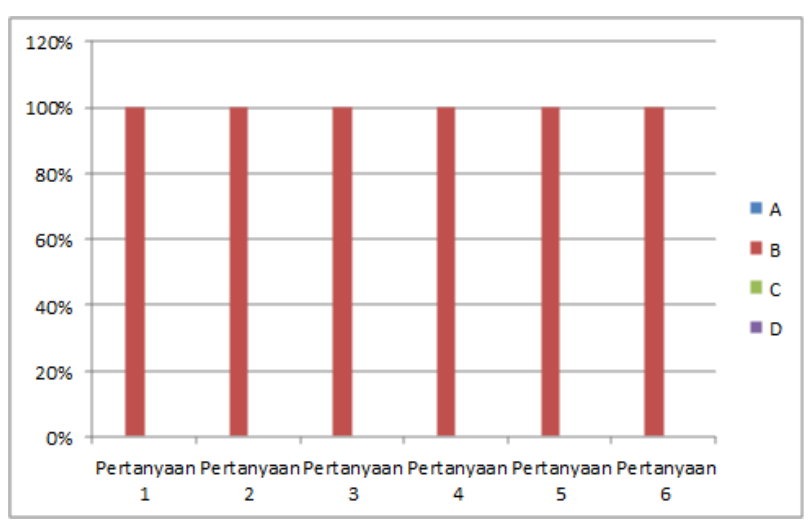

Keterangan :

$\mathrm{A}=$ Pernyataan yang menyatakan jawaban A

$\mathrm{B}=$ Pernyataan yang menyatakan jawaban B

$\mathrm{C}=$ Pernyataan yang menyatakan jawaban $\mathrm{C}$

$\mathrm{D}=$ Pernyataan yang menyatakan jawaban D

Dari grafik jawaban responden di atas didapat hasil bahwa dari 1 orang responden memilih aplikasi mudah digunakan dengan persentase $1 / 1 \times 100 \%=100 \%$, memilih aplikasi mudah di pelajari $1 / 1 \times 100 \%=100 \%$, memilih Tampilan aplikasi menarik $1 / 1 \times 100 \%=100 \%$, memilih aplikasi dapat membantu pekerjaan $1 / 1$ x 100\% $=100 \%$, memilih aplikasi sesuai dengan kenyataan $1 / 1 \mathrm{x}$ $100 \%=100 \%$, memilih hasil kesimpulan dan informasi cukup akurat $1 / 1 \times 100 \%=100 \%$. Berdasarkan persentase jawaban responden tersebut penulis mengambil kesimpulan bahwa aplikasi yang dibangun telah sesuai dengan rancangan yang diinginkan.

\section{Penutup}

\section{A. Kesimpulan}

Hasil pengamatan yang telah dilakukan oleh peneliti pada SMP Negeri 3 Kota Bengkulu dalam penggunaan program aplikasi yang telah dibuat ini menunjukkan respon yang baik dari pihak sekolah. Hal itu terlihat dari beberapa pernyataan yang telah disampaikan pada saat uji coba program untuk melakukan pemilihan juara umum kenaikan kelas.

Selain itu kecepatan dan ketepatan dalam melakukan proses administrasi dan kemudahan yang telah diberikan, maka program aplikasi ini sangat bermanfaatkan dan membantu pihak SMPN 3 Kota Bengkulu meskipun masih memerlukan beberapa perbaikan. Karena sudah sewajarnya perubahan yang terjadi dari pelaksanaan secara manual yang kemudian bergeser ke arah sistem komputerisasi.

\section{B. Saran}

Berdasarkan pembahasan dan kesimpulan yang telah diuraikan di atas, saran dan rekomendasi yang dapat peneliti berikan adalah :

1. Perlunya perluasan fasilitas program yang ada seperti penentuan kriteria penilaian juara umum, pelaksana penilaian dan beberapa hal yang erat kaitannya dengan pemilihan juara umum kenaikan kelas.

2. Perlu banyak pelatihan terhadap pegawai atau karyawan di bidang penggunaan sistem dan menunjang kinerja.

3. Perlunya peningkatan sumber daya manusia sebagai pemakaian/ pengguna program, agar program dapat lebih fisien dan efktif. 


\section{Daftar Pustaka}

Kusumadewi, Sri (2005). Multiple Attribute Making. Jurnal sistem pendukung keputusan Algoritma Genetika.

Pandia, P., 2004. Visual Basic 6 Tingkat Lanjut. Penerbit : Andi. Jogyakarta.

Proboyekti, U., 2007. Rekayasa Perangkat Lunak. Bahan Kuliah. Universitas Kristen Dwipayana. Jakarta.

Rusmawan, U., 2004. Mengolah Database dengan SQL dan Crystal Report dalam Visual Basic 6.0. Penerbit : PT. Elex Media Komputindo. Jakarta.

Rusmawan, U., 2009. Koleksi Program VB 6.0 Konsep ADO. Penerbit : PT. Elex Media Komputindo. Jakarta. 